\title{
Government Oversight, Union Democracy, and Labor Racketeering:

\author{
Lessons from the Teamsters Experience
}

\author{
Michael H. Belzer \\ University of Michigan \\ Richard Hurd \\ Cornell University
}

\section{Introduction}

In his classic 1943 article on union democracy, Herberg argues that unions as institutions are "in the grip of a very real contradiction." On the one hand a union is "a businesslike service organization," while on the other hand it is a "vehicle for... democratic self-determination." Although being pulled in two directions, there is a natural tendency for power to concentrate at the top with a concomitant "narrowing of democracy within the organization." This occurs gradually as elected leaders and staff insulate themselves from political challenge with the implicit approval of the members who "as long as things go well don't want self government. . [but] protection and service" (Herberg, 1943, pp. 406, 410, 412).

In this context, corruption and racketeering are sensational developments which are not central to the issue of union democracy but merely "secondary aggravating factors" (ibid., p. 13). Although Herberg's analysis has withstood the test of time and applies as readily to unions today as it did half a century ago, his point about corruption has been lost. With the McClellan Committee's exposure of labor racketeering and the subsequent Landrum-Griffin Act's melding of anti-corruption and prodemocracy provisions, the two subjects seem to be permanently fused both legally and in the perspectives of labor relations scholars: "From the McClellan committee hearings there emerged a vivid picture in which corruption and undemocratic practices went hand-inhand. Congress there upon acted to establish democracy in labor unions ..." (Gregory and Katz, 1979, p. 538).

This view persists, for example, in the writing of William Gould who decries "the undemocratic and corrupt conduct of some union officials" (Gould, 1993, p. 31). As a consequence, electoral democracy has taken on an elevated stature as the answer to labor's ills. For lawyer Thomas Geoghegan, who has represented insurgent groups in several different unions, "Congress could fix ... the problems of American labor" by reforming the electoral process including: "rank-and-file vote for all officers, ... funding from the union treasury for all candidates," and election oversight by an "outside neutral agency" (Geoghegan, 1991, p. 198).

No wonder that when the federal courts interceded in the Teamsters and ordered direct election of national officers most of the industrial relations community applauded: "The direct election 
of new leadership in the Intemational Brotherhood of Teamsters in 1991 is a welcome development for labor" (Gould, 1993, p. 263). Why? Because of the wide acceptance of the following premise: "The democratic secret ballot-box election of new leadership . . can purge corrupt and criminal elements from the ranks of organized labor's leadership" (Gould, 1993, p. 6). Unfortunately, democratic form has not proved to be a sufficient remedy in the Teamsters, at least in part because of the contradiction identified by Herberg.

Little more than seven years after the first direct election of a national president of the Teamsters we must evaluate what went right and what went wrong. Ron Carey, associated with progressive change and labor union transformation, has been banished for violating the very electoral process that was supposed to save unions from themselves. Jim Hoffa, who carries with him ghosts of Teamsters' past, has been elected to succeed Carey. The Teamsters experience under government oversight demonstrates that democracy alone cannot assure union renewal and that judicial control cannot eliminate all wrongdoing. In fact the challenges are much more complex.

In this paper we examine the federal courts' effort to clean up the Teamsters using legislation originally enacted to fight organized crime. Specifically, we look at the role of electoral democracy in this initiative and trace the experience through the 1991, 1996, and 1998 elections for Teamsters president. Once the story is told, we analyze the experience in the context of union democracy and also consider the relationship between democracy and labor movement transformation.

\section{Background}

The Teamsters and Corruption. The Intemational Brotherhood of Teamsters has been troubled by corruption at the local level since it was founded in Chicago 100 years ago. In Chicago, local leaders conspired with certain business leaders to restrict competition, accept bribes, and stage strikes to benefit some employers at the expense of others. This scheme benefited members as well as hours of work dropped and workers won overtime rates for night work (Leiter, 1957). This duality that characterized the union at the outset has remained, complicating efforts to clean up the union and its image.

At the national level the union was free of overt corruption during the 45-year presidency of Daniel Tobin. This began to unravel when Dave Beck succeeded Tobin in 1952. Beck introduced a new organizational structure by establishing regional Conferences to coordinate bargaining (Gamel, 1972). Arguably the Conferences also facilitated the spread of corruption upward from mob-controlled locals. Within five years Beck was in trouble with the McClellan committee investigating union racketeering. Ultimately he was removed from the AFL-CIO Executive Board and replaced as president by Jimmy Hoffa.

Hoffa soon became the target of the McClellan committee as well, and his questionable practices eventually led to the Teamsters expulsion from the AFL-CIO (Romer, 1962), A Board of Monitors was established by a federal court in 1958, but this proved ineffective due to Hoffa's successful manipulation of the process (Goldberg, 1989a; James and James, 1965; Beizer, 1993), Hoffa was indicted 
in 1962 for violating the Taft-Hartley Act by accepting payments from employers, and he was convicted and imprisoned in 1967 for jury tampering (Sloane, 1991).

Hoffa appointed Frank Fitzsimmons to succeed him because he thought he could control Fitzsimmons from prison. This proved more difficult than Hoffa had anticipated, and the result was internal conflict over power and an era of ineffective national leadership. Ironically, the replacement of Hoffa by Fitzsimmons actually increased the influence of organized crime. Later investigations revealed extensive Cosa Nostra control of the Teamsters during the Fitzsimmons administration which continued throughout the terms of his successors, Roy Williams and Jackie Presser (Neff, 1989; Friedman and Schwarz, 1989; President's Commission on Organized Crime, 1985).

During this period there was a dramatic shift in the trucking industry with reduced government regulation and increased competition, most notably following the passage of the Motor Carrier Act of 1980, This shift presented the Teamsters' leadership with a serious challenge. The absence of any effective strategy to deal with economic and institutional change strengthened the argument of dissidents within the Teamsters that the union was corrupt and incompetent, a potent combination (Beizer, 1994).

Jackie Presser, though ineffective at meeting the external challenges faced by the Teamsters, was adept at enforcing his rule with the help of political operatives and muscle. He served as a double agent for the Federal Bureau of Investigation and organized crime. Presser gained power by informing on his predecessor Williams, and kept it by deftly balancing his corrupt rule against his role as informant (Crowe, 1993; Methvin, 1992), His careful juggling act kept authorities off balance, until the Justice Department stepped into this crisis of policy and clash of goals with a new approach.

The Rationale for RICO. In 1986 prosecutors successfully used the Racketeer Influenced and Corrupt Organizations (RICO) provisions of the 1970 Organized Crime Control Act to take over one of the most corrupt local unions in the U,S, The Provenzano family, central figures in the New Jersey organized crime scene, had dominated local 560 of the Teamsters, Anthony "Tony Pro" Provenzano, the titular head of the family and reputedly a captain in the Genovese organized-crime family, was very close to Jimmy Hoffa throughout his career as a Teamsters leader, Provenzano had been convicted of extortion, labor racketeering, and murder (Sloane, 1991, pp, 167, 343, 364-65, 397), Other organized crime members, namely Michael Sciarra and associates, ruled the local in his absence.

Teamsters Local 560 proved resistant to reform, even by trusteeship. The court-appointed trustee found it extremely difficult to root out corruption that was thoroughly embedded in the social and economic structure within which the union functioned. Individuals like Sciarra were banned but substitutes took over. The first election conducted under court control led to the selection of individuals representing the same organized crime network, so the judge voided the election and re-imposed the trusteeship. After twelve years it appears that the court's direct involvement finally has achieved its objective with the election of anti-corruption candidate Pete Brown as local president on December 18, 1998 (Greenhouse, 1998a). 
The government finally had found a tool that could effectively give it control over union affairs in cases of rampant corruption. The theory is elegant. Convictions of individual Teamsters for individual crimes would not change the nature of the organization as a criminal enterprise, because those removed would be replaced by other corrupt Teamsters. Under RICO, three predicate acts committed by members of an organization acting in concert can be taken as evidence of a criminal enterprise. Once prosecutors surmount the hurdle of proof required to establish the existence of a criminal enterprise, they can request that the court put the enterprise in trusteeship. If the enterprise is a business, they can seize the assets; if it is a union, they can take control of its operations and expel members shown to be associates of organized crime, or expel members who have committed or continue to commit illegal acts in furtherance of that enterprise.

During 1986 and 1987 federal prosecutors began to develop a case against the Teamsters international. The Justice Department filed civil RICO charges in U.S. District Court in Manhattan on June 28,1988 . The case was developed by a young Assistant U.S. Attorney, Randy Mastro, and filed by Rudolph Giuliani, then U.S. Attorney for the Southern District of New York.

The leadership of the Teamsters soon began to fall apart. Jackie Presser developed brain cancer and became less effective just as the FBI released records showing Presser's double agent status. In May of 1988 Presser took a leave of absence for health reasons and died two months later. He was replaced by individuals who did not have the support of the Mafia. Weldon Mathis, the General SecretaryTreasurer, took over temporarily but was beaten by William McCarthy of Boston in a split vote of the Executive Board that took place a week after Presser's death. All of these events - Presser's leave of absence, the filing of the RICO suit, and McCarthy's ascendancy to the presidency - occurred during a period of little more than two months (Crowe, 1993).

The readmission of the Teamsters into the AFL-CIO signaled an intensive effort to attack the RICO suit politically. The Teamsters, playing the role of "defender of democracy," identified themselves with the Polish Union "Solidarity" in an effort to present government's actions as tyrannical. Both politicians and AFL-ClO leaders came to their defense, arguing that the veritable seizure of the union was illegal. Even Teamsters for a Democratic Union (TDU), the reform group, had serious misgivings about the use of RICO because it threatened to become a slippery slope toward government control of labor unions (Bureau of National Affairs, 1989; Geoghegan, 1988; Goldberg, 1989b; Paff, 1987). Due both to arguments made by Justice Department attorney Mike Moroney and to those made by TDU and the Association for Union Democracy, the government eventually decided to emphasize the use of democracy rather than the use of seizure or trusteeship to cure the Teamsters.

Just as the RICO suit approached trial, General Executive Board (GEB) members began signing individual plea bargains with prosecutors. By March 14, 1989 the remaining members of the GEB signed the consent order (United States, 1989), laying the foundation for a near-takeover of the Teamsters by the government. While several prominent local Teamster leaders challenged the settlement in court, the appeal failed and Judge David Edelstein consolidated the case under his control. 


\section{Court Oversight of the Teamsters}

RICO Applied. The RICO consent order was an historic event, the first time a national union had ever been taken over by the government for any reason. The use of RICO itself was controversial because the act had been passed to attack overtly criminal operations and was not intended for a quasipublic institution like a union. As a judicial action the consent order jumped over many constitutional and civil rights arguments, putting the interests of the State (also representing interests of individual members) over union representatives selected by a "legitimate" and legal process. The drastic nature of the solution was possible only because of the extent of criminal activity at the highest levels of the union. The Department of Labor, the Justice Department, and local law enforcement had never successfully taken definitive action against labor racketeering before, nor had they been particularly effective even at incremental enforcement.

The consent order also was significant in that it explicitly imposed democracy on the union. This option might not have been used if the Teamsters' reform movement had not existed already, giving democracy a definite constituency. The Justice Department forced the Teamsters to agree to secretballot elections for International officers, a longstanding plank on the TDU's Bill of Rights. TDU had argued that the right to free and fair election of union officials would be the best antidote to racketeering, corruption, and autocracy.

The consent order allowed the court to appoint three officers of the court: an administrator, an investigations officer, and an election officer, and Edelstein appointed them on May 31,1989. Independent administrator Frederick Lacey had authority similar to that of a trustee in overseeing the non-collective bargaining day-to-day operations of the union. Investigations Officer Charles Carberry was to conduct investigations into the activities and personal associations of individual Teamsters and Teamster leaders. Election Officer Michael Holland was to set the guidelines governing the 1991 election, including election rules, supervision, ballot counting, and certification.

In the next three tumultuous years the enforcement of the consent order wrought enormous change on the Teamsters, forcing out many of the infamous characters for which the union had been known. In the Investigation Officer's report to the union and the court at the end of the first four years of reform, Carberry reported that charges had been filed against 214 individuals and three local unions. The results included 51 individuals permanently barred, 64 resignations with signed agreements that the individuals would never be involved again in Teamster affairs, 53 temporary suspensions, and 30 other signed agreements, including those signed by the locals (Carberry, 1993).

The consent order also required the Teamsters to submit to continued supervision following the democratic election of international officers. The post-election supervision, an entire second phase of oversight, began after new officers took over in 1992. Post-election supervision eventually consisted of an Independent Review Board (IRB) and a Chief Investigator. Retired judge Frederick B. Lacey and former FBI director William $\mathrm{H}$. Webster were original appointees to the IRB. The third member, selected by the union, originally was Harold E. Burke, but eventually he was replaced by labor lawyer Grant 
Crandall. The IRB had the authority to investigate any suspicious activity by Teamster officials and be both proactive and reactive to perceived impropriety.

By signing the consent order under RICO, the Teamsters Union gave up a great deal. By agreeing with the government's charge that they were a "racketeer influenced and corrupt organization," the Teamsters in effect had pled guilty to mob domination. Furthermore, the civil rights of leaders and members were compromised. While citizens enjoy a constitutional right to freedom of association, a "convict" gives up some of those rights, and the Teamsters became "convicts" when they signed the order. For this reason, the IRB only has to prove that an individual Teamster has associated with a member of organized crime or with a banned former Teamster to have committed a serious offense punishable by expulsion. Failure to cooperate with the IRB extends beyond making false statements as well, as charged members may not take the Fifth Amendment. The IRB can act under the union's constitutional authority to take action against those who bring "disrepute" on the union, and during the first five years of its existence the IRB expelled or suspended nearly everyone who failed to cooperate fully (Independent Review Board, 1997).

The 1991 Election. The most visible effect of court oversight was the new process to elect national officers by direct vote of the members. Potential candidates were faced with a significant political challenge: With no relevant experience above the local level to draw on, they needed to establish a national campaign organization with field operations. National leaders in the Teamsters were used to operating inside the halls of power. They knew how to log roll to get things done, but now they had to campaign for office with no opportunity to develop the requisite political skills. The election process required them to collect nominating signatures, win elections for delegates to the convention, and get enough votes at the convention to qualify for a spot on the ballot. Candidates also had to file elaborate campaign finance reports, subject to the scrutiny of other candidates and court representatives.

The incumbent General Executive Board was divided going into the 1991 election. Having never experienced a wide-open election, and arguably in the absence of the controlling influence of the Mafia, board members split into two camps, one backing R.V. Durham and one backing Walter Shea. Durham had been the Teamsters' safety and health director and was considered "clean," with a personal power base in the Southeast. Shea, originally brought into the International as an administrative assistant to Jimmy Hoffa, for all practical purposes had run the union during much of the Fitzsimmons administration and felt that he was ready to assume the presidency. Looking at the Durham and Shea slates one can see the outline of the entire Teamster hierarchy at the end of an era, only a handful of whom remain active today.

Ron Carey, the rebellious leader of UPS Teamsters' Local 804 in New York, sensed an opportunity to take advantage of the incumbents' disarray and announced his candidacy for president in September 1989. Carey gained the support of TDU, the rank-and-file organization of Teamsters opposed to the union's storied corruption and undemocratic practices, and critical of its lack of leadership in the fight to maintain wages and conditions in the face of deregulation. TDU had led an extended fight 
throughout the 1980s in favor of both bottom-up organizing and democratic processes and possessed the organizational framework to get Carey's reform message to the membership.

Conducting a grass-roots campaign and supported by TDU's extensive network of activists, Carey crisscrossed the nation by car, meeting with Teamsters in large units and small, impressing on them that this was their opportunity to make a change. In an historic upset, the rank-and-file slate led by Carey won the election with slightly less than 50 percent of the votes cast. While the election appeared to outsiders to be a "Carey" election, it actually was won by a combination of forces: the Carey "name" and the TDU organization. Neither of them could have won alone, but both together could form an organization capable of delivering the votes (Crowe, 1993; Beizer, 1995).

Oversight during Carey's First Term. Carey's election signaled a new era for the Teamsters. He put his stamp on the organization by setting an aggressive tone with employers and anti-union politicians. He began to beef up certain functions within the international, including organizing and research. In the organizing area he retained Vicki Saporta, the union's head of organizing who had run on the Shea slate during the election, and he allocated a significant increase in funds with which she could hire organizers. In the political arena he hired a professional staff which created a more assertive position within the Washington political environment, and he soon became a leading union voice opposing the North American Free Trade Agreement.

As Carey emphasized organizing and outreach, he brought in and began to energize a new group of staff members well known for their creative and mass-based approach to addressing the crisis of membership decline experienced throughout the labor movement during the 1980s. New staff members in the communications department began to carve out public awareness of the New Teamsters fighting for the "American Dream." Soon after the 1994 Congressional elections Carey and the Teamsters began to put their considerable clout behind the need for change in AFL-CIO leadership and helped lead a revolution that ousted Lane Kirkland and replaced him with John Sweeney as AFL-CIO President. The mood within the "Marble Palace" began to lift as Carey assumed a leading role in redefining unions as member-driven organizations. This change in emphasis also led to a dramatic improvement in the union's public image. Seen as a pariah just a few years earlier, pundits now considered the Teamsters to be a leading force for union reform.

Serious problems, however, continued to undermine his leadership, and 1994 was a pivotal year. The "Old Guard" union leadership, suddenly frozen out of power, continued to resist Carey's new direction (McClure, 1993; Schulz, 1995). During his second year in office Carey had to negotiate a contract with United Parcel Service (UPS). The contract made only minimal improvements over past contracts, retaining the two-tier wage structure for part timers. The ink on that contract was barely dry when UPS, early in 1994, announced a doubling of package size (from 70 to 150 pounds) without bargaining with the union. This affront infuriated Carey, who soon called a national strike against UPS, Whether the strike was legal was debatable (lawsuits were filed on all sides, but all were dismissed eventually), but politically it prompted his opponents to challenge his authority and about half of all local leaders refused to back the strike. About this time Jim Hoffa began to emerge as a potential challenger. 
During the same period it was becoming clear that the International union needed more funds. The per capita tax levied by the international on the locals had been set for a decade at $\$ 3,90$ per month, a pitifully low rate frozen in the union's constitution. Immediately after the aborted UPS strike, Carey tried to raise dues. He attempted to get political support for the dues increase by writing the initiative such that the international would share dues with local unions. The "Old Guard" forces mobilized for this membership vote, and Carey's dues increase failed by a two-to-one margin, Carey's opposition was beginning to find its stride.

Negotiations had begun over the National Master Freight Agreement (NMFA) during this period. The fracas over the UPS package weight limits and the dues increase referendum had distracted key staff members and as a result the union bargaining team was not well prepared. Discussions had begun later than usual in part because of this lack of preparation. Also, Carey by now had become untrusting of other leaders, many of whom indeed were out to get him. The internal problems contributed to failed negotiations, and the result was a lengthy NMFA strike in April 1994 that severely damaged the carriers and the union; both still feel the negative effects. This strike drained the treasury to the breaking point and the union had to turn to the AFL-CIO for a bailout, but it also allowed the International to invoke a constitutional provision allowing it to assess the locals one dollar per member per month until such time as the International's finances crossed a specific threshold. The funding situation has remained dire since that time and the one dollar special assessment remains in effect as of this writing.

The final act during the spring of 1994, immediately after the strike, was a GEB decision to close down the Conferences, The Conferences - Eastern, Southern, Central, Western, and Canadian - were intermediate bodies in the union's structure designed to bring together local and regional leaders within each conference area to work cooperatively to support organizing and bargaining. In recent years, however, critics had charged that the conferences had become a level of wasteful bureaucracy and a haven for double-dippers. Some insiders have argued that Carey actually backed into this action and that if he had intended to use this as a serious strategic power grab he should have transferred the power of the Conferences to existing industry divisions (freight, warehouse, UPS, carhaul, public sector, and others) in an effort to replace the productive organizational function of the Conferences, strengthening the union. In fact, he appeared to retreat after closing down the Conferences, taking no follow-up action.

Although the union continued its aggressive course after the spring of 1994, it seems as if Carey was less "in charge" of events and more reactive. He continued his public role, but some insiders suggested he was more isolated than ever. As the next general election cycle began, with delegate elections in 1995, many activists urged him to be aggressive and confrontational with fence-sitting local officials. Carey held them back, preferring to collect statements of support from those leaders in the period leading up to the 1996 convention. His apparent caution may have doomed the reform process within the union to the successive defeats it was soon to suffer.

Government oversight during this period was uneven, and Carey's opponents charged that the IRB and other court officials had handled Carey with kid gloves. Carey actually was under steady pressure to seek out and remove officials who had run afoul of ethics rules. He trusteed more than 60 
locals during his first term, 20 of them on the direct recommendation of the IRB and many others under indirect pressure. Many times Carey and the GEB recommended punishments of officials, both friend and foe, that were rejected as insufficient by the IRB.

The 1996 Election. The 1996 election in the Teamsters was hotly contested and Carey's margin proved surprisingly thin at the end. The process began in the fall of 1995 with delegate elections and reached a fever pitch at a raucous 1996 convention that accomplished little of substance, but rather was deadlocked in what looked like a weeklong struggle to the death between Carey and his challenger Jim Hoffa.

Carey's strategy on handling the delegate elections proved to be a critical error. From accounts of participants we have learned that Carey decided not to confront local leaders who promised to support his re-election. Some of those officers were opposed the local level by rank-and-file activists, often TDU groups, who believed they were not really "reform" oriented. In many cases, Carey stymied those rank-and-file efforts to push reform issues by insisting on a strategic alliance between reform forces and local leaders who had voiced support for Carey, against the allegedly more dangerous threat posed by Hoffa's candidacy.

Coming into the convention in July, Carey announced that he had the support of a majority of local union officials, but early in the convention this support proved to be diaphanous. Carey lost an early test of strength during the first day, and the rest of the convention degenerated into a test of wits and parliamentary skills between Hoffa forces and TDU activists working with other Carey supporters. To a significant extent, Carey lost the credibility he once had as a reformer and a democrat by resorting to political manipulation to control the convention. Granted the situation was graphically confrontational and chaotic, but the extent of Carey's manipulation of the convention was surprising given his image as a reformer. Most important, the convention displayed the extent to which Carey would be vulnerable in the ensuing election.

The electoral process, as promulgated by 1996 Election Officer Barbara Zack Quindel and approved by the court, proved to be full of loopholes. On the one hand the process was quite rigid regarding convention conduct, specifying the days and times each category of officer would be nominated, restricting demonstrations and similar campaign activity, and requiring local unions to pay for delegates' travel (even detailing the per diem rate). On the other hand, election rules allowed members and nonmembers (those who were not employers) to contribute very large sums of money to election campaigns. Critically, rules for record-keeping were like Swiss cheese, as candidates did not have to record or report contributions of less than $\$ 100$. Both campaigns received hundreds of thousands of dollars, much of which was untraceable.

Hoffa's campaign was decentralized, with field operations controlled by a coalition of local union presidents. While the central Hoffa campaign organization had limited funds, widespread fund raising occurred at the local level based on the political machines of local leaders loyal to Hoffa. These same local machines were able to get out the vote in significant numbers, demonstrating a far more sophisticated political effort than in the 1991 election by either the Durham or Shea slates. 
In contrast to 1991 when his campaign was driven by rank-and-file activists, Carey had turned the operation over to political consultants with a reputation for effective promotion of "progressive" candidates for public office. They saw the election not as retail union politics but as a wholesale broadbrush political operation based on a big budget and mass mailings. Alarmed after nearly losing control of the convention, Carey's campaign seemed to sputter as his political operatives ran scared. Hoffa had significantly more money than Carey did and was able to mount a more aggressive public relations effort.

As late as October 1996, the Carey campaign organization still had not roused itself nor mobilized adequately, as even phone banks were not yet operational. Carey's professional political campaigners had little or no connection to the Teamster membership, and bypassed key rank-and-file leaders who had organizing skills and a political base. To the extent that Carey had a field operation it was based in TDU's organizational network. Critically, however, it seemed as if TDU was hobbled throughout the campaign as it struggled to juggle support for Carey as incumbent (having to defend many unpopular decisions) with their support for Carey as standard-bearer for democratic rank-and-file unionism.

In spite of these difficulties, Carey's slate ultimately won the 1996 election by 26,000 votes, or less than a 52 percent to 48 percent split. Vote margins in many areas were razor thin, and the slate lost in the Central region, reflecting Hoffa's strength in that traditional core bastion of Teamster influence.

The 1996 Election: Aftermath. Applying fund-raising rules like those used in public elections, candidates were not required to report the origins of contributions less than $\$ 100$. The rules allowed contributions by individuals outside the union, and the rules did not limit the size of organizational contributions. This procedure ultimately resulted in widespread wrongdoing on the part of both candidates, though only one of them paid the ultimate price. No sooner had the election been certified than credible charges began to circulate suggesting that Carey campaign operatives had traded funding with political organizations that supported the Democratic party.

During the course of the election, both sides charged hundreds of violations. The Elections Officer investigated these charges and most of them were dismissed. A few charges held up and both sides were adjudged in violation of the rules. These violations include retaliation by the Teamsters Director of Organizing and others against staff members who were not viewed as supporting the Carey agenda (they interpreted a lack of active support for his re-election as lack of support for the Carey agenda), and contributions on behalf of the Hoffa campaign by the Real Teamsters Caucus that actually were contributions of union funds.

The most important charges came after the election was over and certified. Investigation of union records and candidates' campaign finance records suggested that a large sum of money may have been transferred from the Teamsters to certain individuals and consulting firms at times that coincided with the 1996 general election. Indeed, about the time of Carey's inauguration his lawyers became aware of certain potential legal problems. Carey was informed about these charges and he authorized 
attorneys to investigate the situation and soon informed all involved that they should cooperate fully with government investigators, though it took some months for the specific charges to surface.

Eventually investigators determined that certain individuals on Carey's staff, namely professional political operatives Martin Davis, Jere Nash (Carey's campaign manager), and William Hamilton (Teamsters chief lobbyist), were joined by consultant Michael Ansara in a scheme by which they used Teamster funds to leverage contributions to Carey's campaign from political organizations engaged in campaigning for Democratic candidates in the 1996 Congressional elections. This "laundering" of funds, or "swap-scheme," involved the use of $\$ 855,000$ from the Teamsters treasury in trade for funding sufficient to pay for a general mailing of campaign literature to members. The National Council for Senior Citizens, Project Vote, and Citizen Action all accepted contributions from the Teamsters for their get-out-the-vote activities and agreed in return to make contributions to Carey's election fund. The AFL-CIO was implicated for serving as an intermediary. Although the entire illegal effort took place with the agreement of these few non-Teamsters, it ultimately brought down decades of reform efforts by members of TDU and other supporters of union democracy. Ironically, the mass mailing funded by the scheme, performed by Ansara's telemarketing firm, did not go out until more than week after ballots were mailed, probably too late to affect the result.

Judge Kenneth Conboy, acting as "Special Master" in view of the Elections Officer's resignation in September of 1997, ruled that not only should the election be rerun but that Carey should be disqualified (Quindel, 1997; Conboy, 1997). Davis, Nash, and Ansara pled guilty to federal charges, and Hamilton awaits trial. In the summer of 1998 the curtain dropped on Ron Carey, as the IRB banned him from all Teamsters positions for life.

Conboy also ordered the new Elections Officer, Michael Cherkasky, to investigate charges made by Carey's campaign against Hoffa's election fund raising. Carey's camp argued that Hoffa had raised an extremely large sum of money and that he had received funding from mob sources and employers. Cherkasky ruled on April 27, 1997 that although Hoffa and his campaign had violated election rules and the law, the violationswere not severe enough to warrant disqualification. Some of the charges against Hoffa were serious. Cherkasky charged Hoffa with accepting $\$ 167,675$ from an employer, Richard Leebove and RL Communications (a Landrum-Griffin violation). Hoffa also was charged with being untruthful about Leebove's role, "testifying under oath" that he was only marginally involved in the campaign. On the contrary, Leebove, a former operative for Lyndon LaRouche, was known to the media and to key individuals within the Hoffa campaign organization as "the brains of the campaign." Cherkasky found that Leebove actually performed work for Hoffa while being paid for doing business for Teamster local-union clients, thus constituting a transfer of union funds to pay for Hoffa's campaign. He also found that the campaign employed convicted felon Kevin Currie through payments to Currie's wife. In spite of these findings Cherkasky ruled that the violations were not severe enough to cause Hoffa to be disqualified from running for Teamsters' President (Cherkasky, 1998).

Carey's disqualification hit the Carey camp and TDU hard. For months "reform" forces were in disarray, sure that these charges would be proven false and Carey would return to office. Eventually, 
however, it became clear that whether Carey had known of the swap scheme or not, he would be held responsible as the fiduciary - it happened on his watch.

Carey apparently wanted to name a successor, and his support went to Ken Hall, his partner in bargaining the 1997 UPS contract. Hall, however, was unable to mount a campaign and the "reform" forces' efforts languished. In May it became clear that Hall would not be able mount a campaign and Tom Leedham, Western Regional Vice President and director of the union's Warehouse Division, stepped into the breach. Leedham was unable to attract support from traditional Teamster leaders aligned with Carey (such as John Morris of Philadelphia, an "old school" machine politician), so his slate was more narrowly based among those who advocated "rank-and-file-power" unionism than was Carey's. Leedham indeed articulated a very clear vision of where the Teamsters needed to go and showed that he could campaign tirelessly to demonstrate his leadership.

The 1998 Rerun Election. In 1998 the Teamsters re-ran their 1996 election, but the cast of characters had changed somewhat. Jim Hoffa was the early front-runner as he had years of exposure and solid funding. Tom Leedham led the former Carey forces with a campaign that literally started at the very last minute and plugged into the TDU's grass-roots organization. John Metz of St. Louis, director of the union's public-sector division, headed a spoiler slate and did not campaign.

Hoffa began the 1998 rerun election with a strong war chest and solid name recognition. The media immediately announced that he was the favorite, a "shoo-in" for election as Teamster president. Though Hoffa's early campaigning was rather limited, his pace picked up during the fall, apparently because a poll commissioned by his campaign showed the race much tighter than originally expected. Hoffa's campaign drew support from leaders and members who either had never accepted the "reform" concepts advocated by Carey and TDU or who had come to the conclusion that Hoffa alone had the personal credibility to end the conflict within the union and bring unity to the Teamsters.

During the 1998 campaign Leedham campaigned six or seven days per week, frequently 18 hours per day. He estimated that during his campaign he shook nearly 100,000 hands and visited Teamster workplaces throughout the nation. He campaigned on a shoe string, sleeping in members' homes to save funds, but ultimately Leedham was unable to overcome the name recognition disadvantage, John Metz, the leader of a third slate made up primarily of Carey's more traditional supporters (key among them John Morris), hardly campaigned at all. He did make use of free advertising in the Teamster magazine, much of it devoted to negative campaigning aimed at Hoffa.

Ultimately Hoffa won with 54,5 percent of the votes cast, Leedham received 39,3 percent and Metz received 6,2 percent (Bearth, 1999), Since Leedham had begun his campaign barely six months earlier as an unknown except among activists, his showing may be seen as remarkable. While Hoffa claimed a mandate for change, voter turnout was barely 28 percent of the membership, down from 34 percent in 1996.

Although the election results as announced on December 5 are indisputable, charges filed by the IRB in subsequent weeks cast a shadow over the outcome. The IRB formally charged three of Hoffa's 1998 running mates, with the actions of one of them directly linked to Hoffa himself. Vice president 
elect Tom O'Donnell was charged for his role in the 1996 election when he hired convicted felon Kevin Currie to work for the Hoffa campaign. Recall that employment of Currie was one of the charges against Hoffa which was substantiated by the investigation of Elections Officer Cherkasky, Charges also have been filed against one of Hoffa's Southern regional vice presidents, J.D, Potter, for falsely reporting illegal contributions to the Hoffa campaign, and against Western regional vice president Jim Santangelo for improper financial practices (Greenhouse, 1998b), Other charges may follow, as Hoffa Eastern regional vice president Dan DeSanti allegedly had a campaign meeting with suspended former Local 107 President Tom Ryan, according to information released by the IRB on December 10.

\section{Analysis}

Union Democracy. Union democracy is a topic which has received scant attention from scholarly researchers in recent years. Fortunately, Strauss contributed an overview of the topic to the 1991 IRRA volume. The State of the Unions. Strauss' piece plus several commentaries on the Teamsters case provide a framework which facilitates analytical treatment of the facts that we have presented.

As Strauss points out, there are two competing definitions of union democracy. According to one view, the objective is a high level of rank-and-file participation so that the union empowers workers to exercise voice directly in decisions that affect them (both within the union and on the job). Under the alternative definition, the key contribution of unions to democratic society is in their role as a countervailing force to employers, and to fulfill this function a union must display unity through discipline and administrative efficiency. It is not easy for a union simultaneously to promote member involvement and to maintain the discipline necessary to speak as one voice. Unions therefore face a "democracy dilemma" (Strauss, 1991, pp. 204-5).

Fraser (1998) takes the dilemma one step further. He notes that unions perform at least three roles which are not always compatible: rank-and-file participation and mobilization; representation of members' interests vis-à-vis employers; and organization for combat including the imposition of "solidaristic discipline." Both Fraser and Strauss point out that in order to cope with these competing demands, elected leaders and union staff tend to exert control over the operation of the union bureaucracy and to insulate themselves from the vagaries of rank-and-file pressure.

In practice member participation is channeled into periodic mobilization in support of contract negotiations, while day-to-day involvement is limited to a small cadre of stewards who may be elected or appointed. Most workers adapt to this approach and come to think of the union as an occasionally militant insurance agency that provides representation services day to day and coordinates strikes when necessary.

If the concept and experience of union democracy are ambiguous, then it comes as no surprise that the role of government in promoting this democracy also lacks clarity. For many political conservatives, government policy should protect the individual rights of union members (including the right not to join); for them, duty of fair representation requirements and provisions allowing members

to withhold dues payments that support political activity are essential elements of democracy. For many political liberals, on the other hand, union democracy means the right to vote for leaders with a 
preference for some electoral choice, i.e., more than one candidate. However, democracy is not seen by liberals merely as an end in itself, but also as the best antidote to union corruption and autocracy. As Strauss summarizes this point: "Democratic rules serve to foster democracy (however defined) and reduce corruption. But these rules need to be enforced." He goes on to describe the pending (1991) Teamsters election as a "critical test of what the law can accomplish" (Strauss, 1991, p. 232).

Enforcement is more difficult to accomplish in some settings than in others. Industrial unions with roots in the $\mathrm{ClO}$ are highly centralized; if the national union operates democratically, then it reasonably can be assumed that the locals are democratic. Most of these unions meticulously follow federal regulations in conducting their national elections and in that sense they are democratic, although many of them (such as the UAW) operate as one-party states and have throughout their history.

Craft unions with roots in the AFL are a different matter entirely. Most of them are decentralized with substantial local union autonomy. This makes enforcement far more complicated since each local operates under its own rules and in the context of its own institutional history. Even national elections may be difficult to evaluate since in most unions they are conducted via convention votes by delegates who are selected at the local level. The Teamsters are an AFL union, and journalist Phil Dine has reasonably posed the question, "Did those [in the government] who set out to reshape the Teamsters understand its culture and history" (Dine, 1998)?

When considered in the context of the dramatic changes which have been underway in the labor movement over the last decade, the challenge of promoting union democracy is even more complex. Intensified market pressure caused by technological change, deregulation, and globalization of markets has wreaked havoc, but the inflexible practices of most unions also have contributed to decline. In this environment progressive unionists have struggled to lead their cohorts down the rocky road to transformation. In its purest form, this initiative has grown out of rank-and-file insurgencies including that of TDU and of the UAW's New Directions movement. These movements argue that unions should pursue an "organizing model," mobilizing members to practice activist unionism every day on the shop floor. Bob Muehlenkamp summarized the concept as "organizing for everything we do" (Muehlenkamp, 1991). In 1988 when he issued this call Muehlenkamp was with the National Union of Hospital and Health Care Employees; he joined Ron Carey's staff as organizing director in 1992.

Many idealists have embraced the cause of the insurgents. In a "radical retort" to the Fraser article cited above, Aronowitz defends grassroots union democracy on two grounds: unions controlled by the rank and file will be better able to wage class war; and participatory democracy is the appropriate antidote to the "authoritarianism of liberal [electoral] democracy" (Aronowitz, 1998, p. 84). Even Aronowitz, however, recognizes the potential futility of his own idealism, admitting that in the context of the U.S. industrial relations system unions naturally will gravitate to the insurance-agency approach, or the "servicing model" as it is often called.

More pragmatic unionists, including the current leaders of the AFL-CIO, are attempting to transform unions from the top down. There is little indication that union members are interested in the 
degree of daily activism envisioned in the organizing model, and no credible evidence at all that "class war" is more than a leftist intellectual dream. Thus progressive union leaders and staff are moving beyond the organizing model to develop strategies to regain market power through increased organizing, more effective political action, and selective reliance on militant confrontations. Targeted mobilization of members plays a key role in these efforts but is not an end in itself (Fletcher and Hurd, 1998).

This top-down approach to transformation is not satisfactory for supporters of rank-and-file insurgency, such as Kim Moody, who complains of the current AFL-ClO leaders, "Union democracy is not on their radar screen" (Moody, 1998). Others are more sympathetic. To return to Fraser, he argues that a strong institutional labor movement and its attendant bureaucracy are in fact what members want. Furthermore, procedural democracy in large national unions may ultimately "replicate contemporary electoral politics" and have "little to do with the rank and file" (Fraser, 1998). He cites the 1996 Teamsters election in support of this point.

Ultimately, the current efforts by the AFL-ClO to transform the labor movement can be understood in the context of Strauss' second definition of union democracy: Unions are democratic to the extent that in the defense of workers they are an effective countervailing force to employers. As Fraser observes, "From afar it is all too easy to declaim preoccupation with power while failing to recognize the precariousness of the union institution itself (Fraser, 1998). Leaders and staff at the AFL$\mathrm{ClO}$ want member involvement and greater effectiveness and to some extent they see involvement as a lever for effectiveness. But the primary focus has to be on results, so concern for effectiveness predominates.

Teamster Democracy. With its strong tradition of local union autonomy, the Teamsters union which entered into the consent agreement in 1989 was anything but homogeneous. To be sure, some locals were controlled by leaders who made sweetheart deals and were influenced by organized crime. Far more common were locals that operated as traditional business unions embracing the servicing model/insurance agent approach. Some leaders of these servicing model locals collaborated with or at least tolerated their corrupt counterparts elsewhere in the Teamsters. But many other leaders steered clear of questionable elements in the union and operated clean locals. Some went so far as to urge democratic reforms and an end to corruption (albeit in the context of traditional servicing model unionism). There also were a growing number of locals embracing the organizing model approach, in part due to the influence of nearly twenty years of insurgency and rank-and-file militancy instigated by TDU.

The three slates of candidates that ran in the 1991 Teamsters' election reflected the interests of these three constituencies. The "incumbent" faction was represented by both Durham and Shea slates, though some may argue that the Shea slate had more corrupt old-line leaders than did the Durham slate. Both slates included leaders who wanted to preserve the tradition of local autonomy, even if it meant continuing to tolerate corruption in some segments of the union. They also included leaders who were intolerant of corruption in their own locals but who agreed on a common vision of the servicing 
model of unions that discouraged member involvement. The mixed motivations of these slates' leaders, however, did not include support for the organizing model.

Carey clearly was a threat to corrupt elements because of his reputation as a reformer. He also was perceived as somewhat of a threat to entrenched local leaders because of his historic willingness to challenge the Teamsters hierarchy and because of his current willingness to embrace TDU's more grassroots model. His opposition to corruption won him the support of organizing model locals and members throughout the country who wanted to break away from the corrupt history of the Teamsters, but Carey's expertise and instincts personally were firmly rooted in the servicing model. His endorsement by the TDU created problems for more traditional local leaders, but he was able to gain enough support among those who wanted a change to guide this coalition to victory.

This characterization of the three candidacies oversimplifies the political dynamics of the first election, as advocates of the servicing model who tolerated some corruption split their vote, and the election was won by a coalition between advocates of the anti-corruption servicing model and the organizing model (which gained nearly 50 percent of all votes cast). No slate can be characterized entirely with one of these generalizations, as Vicki Saporta, organizing director at the time of the consent agreement and respected throughout the labor movement for her innovative bottom-up organizing strategy, ran on Shea's slate even though her perspective likely better fit the Carey team. On the other hand, some of those on Carey's slate later were charged with inappropriate dealings and removed as a result of IRB investigations. True to form, however, eventually more of those on Durham's and Shea's slates left the Teamsters under a cloud than left the Carey administration under similar circumstances.

Carey's win was a surprise inside and outside of the Teamsters. It reflected an unexpected breadth of support for change among local leaders and members. His victory was by no means complete, however, since he won only a plurality of the vote with only 28 percent of members voting and did not subsequently gain the support of a majority of local leaders. Many leaders of servicing model locals who had opposed Carey in the first election supported him afterwards, although in retrospect we might question the depth of their commitment. But many others maintained their distance or openly challenged his leadership, setting the stage for ongoing conflict.

When Carey took office in 1992 he implemented a wholesale replacement of key national union staff. In a break with tradition, most of the newcomers were hired from outside the Teamsters with the typical individual an experienced professional from another union with a reputation for innovation and a commitment to labor's revitalization. Joining Carey were Eddie Burke from the Mineworkers as chief of staff, Judy Scott from the UAW as chief counsel. Bob Muehlenkamp as organizing director, Marilyn Sneiderman from the George Meany Center as education director, Ron Carver from the UE as director of corporate campaigns, and many others.

While his new staff set out to change the Teamsters culture from above, Carey cooperated with the IRB's investigation into corruption. Where the IRB found evidence of corruption or of collaboration with former Teamsters expelled for corruption, Carey established trusteeships. Eventually Carey 
trusteed more than 60 locals scattered throughout the Teamsters, many of those in traditionally corrupt areas such as New York and New Jersey. In a parallel move, Carey first feuded with and then disbanded the Teamster Conferences, intermediate bodies which had coordinated activity at the regional level and which insulated locals from national control to some extent (while allowing local leaders to draw additional salaries as described above).

Carey's high-powered staff, his use of trusteeships, and his dissolution of Conferences were part of an effort to centralize power in the national union. At the same time, he maintained his uneasy alliance with the TDU and with organizing model locals as he sought to establish his strategic coalition. In Strauss' framework, Carey essentially was attempting to create a solution to the democracy dilemma by simultaneously centralizing control and promoting rank-and-file activism.

To step outside of the Teamsters briefly, Carey was widely applauded for his efforts in the labor movement, particularly by those union leaders and staff described in the preceding section as pragmatic progressives working to lead union transformation from above. In due time Carey established close ties with a small circle of national union presidents who shared this perspective including John Sweeney of the SEIU, Gerald McEntee of AFSCME, and Rich Trumka of the UMW (who had himself risen to power via a government-imposed direct election). As a member of this group Carey embraced the goal of transformation and became a key player in the 1995 ouster of Lane Kirkland as President of the AFL-CIO and in the subsequent victory of the "New Directions" slate headed by Sweeney and Trumka.

The ascendancy of New Directions was not matched by good fortune for Carey's "New Teamsters," As detailed above, the 1993 UPS contract was a disappointment; the 1994 strike over the National Master Freight Agreement drained the union treasury; the effort to raise dues was soundly defeated; and initiatives to restructure and centralize the union were widely resisted. Throughout Carey's first five years in office his opponents within the union resisted him at every tum and attempted to undermine virtually every aspect of his program.

In spite of these difficulties, Carey entered the 1996 Teamsters election year secure in the presumption of continued support from his diverse coalition of local leaders representing a majority of members. Nonetheless, the candidacy of Jim Hoffa was a serious enough threat for Carey to assemble a high-powered team of political consultants to coordinate his campaign. The convention debacle exposed the lack of commitment among certain elements of Carey's coalition, particularly more traditional forces committed to both the servicing model and local union autonomy. It also exposed the weakness inherent in Carey's strategic compromise with those more traditional forces: everything he did to appease them (such as discouraging TDU activists from running against them in delegate elections) set him up for the disaster that befell him during the convention.

Although the Carey campaign (and subsequently Leedham's campaign) portrayed Hoffa as captive to corrupt elements, his support actually was much broader. The actions of the IRB and the corresponding trusteeships had done little to challenge traditional servicing model unionism, and had in some ways reinforced the appeal of local union autonomy, Hoffa assembled a network of local leaders 
who were leery of efforts to centralize the union and who yearned for a return to an environment where their own authority was undisputed.

Hoffa's commitment to traditional servicing model unionism is clear in his campaign materials: "Today we need a leader who understands the 'ins and outs' of labor law Experienced leaders like Jim Hoffa know how to fight the employer and win," Nowhere in the Hoffa campaign was there a hint of commitment to members activism; rather, rank-and-file involvement is limited to voting for " ... the leadership it believes can solve its problems over the long term," Furthermore, Hoffa strongly endorsed limiting the use of trusteeships and returning authority to local unions and opposed Carey's effort to raise the per capita tax above the current level of $\$ 3,90$ per member per month.

Whereas Carey's conceptualization of democracy attempted to resolve the democracy dilemma by combining rank-and-file involvement with strong leadership committed to transformation, Hoffa's is much simpler. Democracy is limited to Strauss' second definition, with unions serving as a countervailing force to employers. For Hoffa this is best achieved by relying on a skilled lawyer/negotiator in the national presidency, combined with local control of the day-to-day representation of members.

Hoffa's message had broad appeal to local leaders and the depth of support displayed the convention should have served as a wake up call for the Carey campaign team. The campaign actually continued to languish as Carey, beset by physical pain (both knees were replaced after the election) and struggling to maintain his strategic coalition, did not shift gears and mobilize the membership until rather late. During the fall of 1996 (months after the convention) Carey's campaign strategy was adapted from public electoral politics, complete with a fund-raising operation which eventually overstepped legal boundaries. Carey's allies in other unions could not resist the temptation to assist their associate in his time of need, as they apparently believed that the coordinated effort to transform unions and rebuild the labor movement was in danger of unraveling.

Ironically, it was only after Carey's tainted election victory that the 1997 UPS contract fight actualized his vision for the Teamsters. Carey's crackerjack national staff developed a model strategy, including a clear public relations message about UPS's reliance on temporary workers and low wages, along with a national network of UPS workers developed using "member-to-member" mobilization. The AFL-CIO's financial guarantee of strike benefits was the icing on the cake. Unfortunately for Carey, the ink was barely dry on the contract before the elections officer voided the 1996 election due to campaign fund-raising improprieties.

Although irregularities were uncovered in both the Carey and Hoffa campaigns, there is an important difference. The money funneled into Carey's campaign came from the national union treasury in a "you scratch my back and I'll scratch your back" scheme that indirectly traded funding of liberal organizations' get-out-the-vote efforts for contributions to Carey's campaign. Ironically, the "rank-andfile" Carey had access to these funds due to his control of the national organization. Some of Hoffa's tainted funds, on the other hand, came from local union treasuries in a more "traditional" way, as local union leaders granted themselves bonuses and raises that in tum were kicked back to Hoffa's treasury. 
Others came from employers, such as Leebove, and most other funding came from local "Hoffa '96" campaign organizations that kept insufficient records to allow tracing of the funds.

Though these practices of both campaigns were flawed, the legal distinction was defining. In his position as national union President, Carey bore responsibility for the illegal funding scheme and was removed from office, barred from running in the 1998 election, and ultimately barred from the union. Since it was local union presidents who shifted monies to Hoffa, and since he was the challenger and not engaged therefore in "official" wrongdoing, he was one step removed from the violations and thereby escaped with a reprimand.

Only one piece remains to complete the Teamster democracy picture. Tom Leedham eventually emerged as Hoffa's primary opponent in 1998. His view of democracy, as reflected in his campaign, is much closer than Carey's to Strauss' first definition - a high level of rank-and-file involvement with the union empowering workers to exercise voice. His support among leaders came primarily from those who support the organizing model, including TDU locals. Most leaders of servicing model locals who had participated in the Carey coalition defected to Hoffa, as Leedham received support from perhaps 10 percent of local leaders. In spite of this apparent limited appeal, his grassroots outreach directly to members ultimately attracted far more support than most observers had anticipated: Leedham carried the majority of votes in freight, UPS, airline, and warehouse locals in the Teamsters traditional strongholds, while losing big in miscellaneous multiple jurisdiction locals whose members tend to be inactive and strongly dependent on local leadership power (Roberts, 1998). The fact that he won 40 percent of the vote indicates that the 1998 election did not necessarily resolve the implicit debate about what vision of democracy best fits the Teamsters.

\section{Conclusion: Has Government Oversight Promoted Union Democracy?}

Government oversight of the Teamsters has been pursued with twin objectives: root out corruption and promote democracy. There also has been an implicit expectation (at least on the part of academics in the field of industrial relations) that a by-product of democracy and reduced corruption would be institutional transformation. The results have been mixed. Quantitatively at least, the effort to reduce corruption has had a major impact. Scores of local and national officials have been removed from office and about 60 locals have been placed in trusteeship. Union members arguably are more involved in their union and in leadership processes, and some evidence suggests that union militancy and effectiveness may result from this involvement (Witt and Wilson, 1999).

Effective democracy, on the other hand, has proved to be more elusive. The imposition of a model of public electoral democracy unintentionally provided incentives to import questionable fundraising practices as well. This kind of impropriety is widely viewed as unacceptable but prevalent in our public electoral process; it is even less acceptable in the union environment. Union elections are more vulnerable to manipulation than are elections for governmental office because so much of unions' influence lies in the private sphere inhabited by workers and employers as individuals.

The net impact has been to increase barriers to transformation both inside and outside of the Teamsters, Ron Carey, the most effect voice for transformation, has been silenced after succumbing to 
the temptations crafted by his advisors and political consultants. Meanwhile, conservative Republicans in Congress have had a field day with the steady streams of evidence uncovered by the IRB related to both corruption and election fraud. This has allowed labor's political enemies to purse an anti-union agenda (national right-to-work, limits on political activity, reduced funding for the NLRB, and others) under the guise of fighting corruption and defending democracy.

Optimistic proponents of government oversight of the Teamsters apparently were not fully cognizant of institutional realities. Sidestepping the corruption question for a moment, for nearly ten years we have witnessed a struggle between the defenders of the status quo (local autonomy, servicing model unionism) and the promoters of transformation (democratic centralized authority, organizing model unionism). Although there have been differences within both schools of thought, Shea, Durham, Hoffa, and Metzhave all defended the status quo while Carey and Leedham have promoted transformation. The intensity of feeling about the strategic and organizational differences between the two camps has to some extent overshadowed concern for democracy or corruption. It is not surprising that in 1996 both presidential candidates pushed the edge of the envelope regarding campaign practices, because they were fighting over the future direction of an institution to which they are devoted.

The alleged complicity of other labor leaders in the 1996 election violations also can be understood in this light. The officials from the AFL-CIO, AFSCME, SEIU, and other unions who apparently contributed to the Carey campaign, along with the progressive staff professionals brought to the Teamsters by Carey, all are committed to rebuilding unions around a strategy which emphasizes organizing, increased political action, and member mobilization. The Teamsters were viewed as integral to the intense effort being waged to create a new labor movement.

Writing in the Harvard Business Review, Kotter counsels those who are leading transformation efforts in corporations that they must remove those who are blocking progress. Achieving radical change is almost impossible unless the leader is able to rally all key participants in support of the new vision (Kotter, 1995, pp. 64-65). In 1996 the Teamsters were clearly divided, and the attention of Carey and his supporters was on how to get the blockers out of the way. Their zeal to accomplish this objective apparently clouded their judgement regarding both the anti-democratic implications of their actions and the potential legal fallout.

The contest over the future direction of the labor movement is not yet resolved. Advocates of tradition continue to compete for votes and for support with those promoting transformation. But the central challenge remains. Labor unions have declined in membership, influence, and bargaining power for the last three decades, and something must be done by union members and leaders to reverse the trend. For unions, the status quo is not an option. As they struggle to lead change, union officials will continue to grapple with the contradictions inherent in union democracy. And while democracy is not sufficient to assure renewal, it is necessary if transformation is to take hold and be self sustaining. 


\section{REFERENCES}

Aronowitz, Stanley. "Democracy is Key." New Labor Forum 3 (Fall/Winter 1998): 82-93.

Bearth, Daniel P. "Hoffa Takeover Delayed by Leedham Protest." Transport Topics. Alexandria, Va., January 18, 1999.

Beizer, Michael H. Collective Bargaining in the Trucking Industry: The Effects of Institutional and Economic Restructuring. Ithaca, N.Y.: Cornell University, 1993.

. "The Motor Carrier tndustry: Truckers and Teamsters Under Siege." In Contemporary Collective Bargaining in the Private Sector, edited by Paula B. Voos. Madison, Wise: Industrial Relations Research Association, 1994, pp. 259-302.

. "Collective Bargaining After Deregulation: Do the Teamsters Still Count?" Industrial and Labor Relations Review 48 (July 1995): 636-55.

Bureau of National Affairs. "Dissident Teamsters Group Seeks to Intervene in Government's RICO Case Against Intemational." Daily Labor Report, January 25, 1989.

Carberry, Charles M. "Investigations Officer's Report." Washington D.C: Independent Review Board, Office of the Chief Investigator, July 22, 1993.

Cherkasky, Michael G. "Decision in In re: Carey Slate (Post-47-EOH)." Washington D.C: Office of the Election Officer for the International Brotherhood of Teamsters, April 27, 1998.

Conboy, Kenneth. "Decision In Re Cheatem etal. (Post-27-EOH, Post-29-EOH, Post-31-EOH, Post-32EOH, Post-33-EOH, Post-35-EOH, Post-37-EOH, Post-39-EOH, Post-40 EOH, Post-42-EOH, Post43-EOH, Post-44-EOH, Post-51-EOH)." Washington, D.C: Office of the Election Officer for the International Brotherhood of Teamsters, November 17, 1997.

Crowe, Kenneth C. Collision: How the Rank and File Took Back the Teamsters. New York: Charles Scribner's Sons, 1993. . "Charges Mar Hoffa Win." Newsday, December 6, 1998.

Dine, Phil. "Democracy Has Left Teamsters Leaderless and Bleeding, Badly." St. Louis Post Dispatch, October 25, 1998.

Fletcher, Bill, Jr. and Richard W. Hurd. "Beyond the Organizing Model: The Transformation Process in Local Unions." In Organizing to Win, edited by Kate Bronfenbrenner et. al. Ithaca, N.Y.: Cornell University Press, 1998, pp. 37-53.

Fraser, Steven. "Is Democracy Good for Unions?" Dissent 45 (Summer 1998): 33-39.

Friedman, Allen and Ted Schwarz. Power and Greed: Inside the Teamsters Empire of Corruption. New York: Franklin Watts, 1989. 
Gamel, Donald. The Rise of Teamster Power in the West. Berkeley: University of California Press, 1972. Geoghegan, Thomas. "Union Suit: A Wrong Cure for the Teamsters." New Republic, August 22, 1988, p. 8.

Which Side Are You On? Trying To Be for Labor When It's Flat on Its Back. New York: Penguin Books USA, 1991.

Goldberg, Michael J. "The Teamsters' Board of Monitors: An Experiment in Union Reform Litigation." Labor History 30 (Fall 1989a): 563-84.

. "Cleaning Labor's House: Institutional Reform Litigation in the Labor Movement." Duke Law Journal (September 1989b): 903-1011.

Gould, William B. IV. Agenda for Reform: The Future of Employment Relationships and the Law. Cambridge, Mass.: MIT Press, 1993.

Greenhouse, Steven, "Once-Corrupt Teamster Local Has First Election in a Decade," New York Times, December 20, 1998a.

. "A Third Hoffa Vice President Faces Charges," New York Times, December 18, 1998b.

Gregory, Charles O, and Harold A, Katz, Labor and the Law. New York; Norton, 1979.

Herberg, Will, "Bureaucracy and Democracy in Labor Unions," Antioch Review 3 (Fall 1943): 405-17.

Independent Review Board, "Independent Review Board's Five-Year Report (1992-1997) To Honorable David N, Edelstein, United States District Judge," Washington, D,C,: Independent Review Board of the International Brotherhood of Teamsters, November 6, 1997,

James, Ralph and Estelle Dinerstein James, Hoffa and the Teamsters: A Study of Union Power. Princeton: D. Van Nostrand Company, 1965.

Kotter, Robert, "Leading Change: Why Transformation Efforts Fail," Harvard Business Review 13 (MarchApril 1995): 59-67.

Leiter, Robert D, The Teamsters Union: A Study of Its Economic Impact. New York: Bookman Associates, 1957.

McClure, Laura, "The New Teamsters: Ron Carey and the Reformers One Year Later," Dollars \& Sense 10 (1993): 22.

Methvin, Eugene $\mathrm{H}$, "The Liberation of the Teamsters: End of Organized Crime Influence on Labor Unions," National Review 44 (March 30, 1992): 35.

Moody, Kim, "The Business Union Shortcut: When Will We Learn?" Labor Notes 226 (January 1998): 11. Muehlenkamp, Robert, "Organizing Never Stops," Labor Research Review 17 (1991): 1-5. 
Neff, James, Mobbed Up: Jackie Presser's High-Wire Life in the Teamsters, the Mafia, and the F.B.I. New York: Atlantic Monthly Press, 1989.

Paff, Ken, "Let the Teamsters Vote: We Need Union Democracy, Not a Government Takeover," Washington Post, June21, 1987.

President's Commission on Organized Crime, "In the Matter of Roy L, Williams, a Witness Subpoenaed by the President's Commission on Organized Crime," In The Edge: Organized Crime, Business, and Labor Unions -Appendix. Washington, D,C,: U,S, Government Printing Office, 1985.

Quindel, Barbara Zack, "Decision of Election Officer in In re: Jeraldine Cheatem, et al. (Post-27-EOH, Post29-EOH, Post- 31-EOH, Post-32-EOH, Post-33-EOH, Post-35-EOH, Post-37-EOH, Post-39-EOH, Post- 40-EOH, Post-42-EOH, Post-43-EOH, Post-44-EOH, Post-51-EOH)," Washington, D,C,: Office of the Election Officer for the International Brotherhood of Teamsters, 1997.

Roberts, William, "Hoffa Failed to Win over Union's Soul," Washington, D,C,: Journal of Commerce, December 14, 1998, p, 1A.

Romer, Sam, The International Brotherhood of Teamsters: Its Government and Structure. New York: John Wiley, 1962.

Schulz, John D, "'Back to the Future' Teamsters' Campaign Conflicts with Present Trucking Realities," Traffic World, September 4, 1995.

Sloane, Arthur A, Hoffa. Cambridge, Mass,: MIT Press, 1991.

Strauss, George, "Union Democracy," In The State of the Unions, edited by George Strauss, Daniel G, Gallagher, and Jack Fiorito, Madison, Wise: Industrial Relations Research Association, 1991.

United States v. International Brotherhood of Teamsters, 88 Civ. 4486 (DNE) (SDNY).

Witt, Matt and Rand Wilson, "The Teamsters' UPS Strike of 1997: Building a New Labor Movement," Labor Studies Journal 24 (Spring 1999): forthcoming. 